\title{
Message From the Editor-in-Chief
}

\author{
Hiroaki Shimokawa, MD, PhD
}

Dear Colleagues,

On behalf of the Circulation Journal, I would like to let you know the top 40 papers most frequently cited in the 2011 issues of the Circulation Journal. The number in the parenthesis denotes the number of citations in Circulation Journal in the year of 2011.

1. (18) Takayama T, Hiro T, Yamagishi M, Daida H, Hirayama A, Saito S, et al; COSMOS Investigators. Effect of rosuvastatin on coronary atheroma in stable coronary artery disease: Multicenter coronary atherosclerosis study measuring effects of rosuvastatin using intravascular ultrasound in Japanese subjects (COSMOS). Circ J 2009; 73: $2110-2117$.

2. (15) Yasuda S, Shimokawa H. Acute myocardial infarction: The enduring challenge for cardiac protection and survival. Circ J 2009; 73: 2000-2008. (Review)

3. (14) Cutlip DE, Windecker S, Mehran R, Boam A, Cohen DJ, van Es GA, et al; Academic Research Consortium. Clinical end points in coronary stent trials: A case for standardized definitions. Circulation 2007; 115: 2344-2351.

(14) Matsumoto N, Nagao K, Hirayama A, Sato Y. Non-invasive assessment and clinical strategy of stable coronary artery disease by magnetic resonance imaging, multislice computed tomography and myocardial perfusion SPECT. Circ J 2010; 74: 34-40. (Review)

5. (13) Moses JW, Leon MB, Popma JJ, Fitzgerald PJ, Holmes DR, O’Shaughnessy C, et al; SIRIUS Investigators. Sirolimus-eluting stents versus standard stents in patients with stenosis in a native coronary artery. $N$ Engl $J$ Med 2003; 349: 1315-1323.

6. (11) Okazaki S, Yokoyama T, Miyauchi K, Shimada K, Kurata T, Sato H, et al. Early statin treatment in patients with acute coronary syndrome: Demonstration of the beneficial effect on atherosclerotic lesions by serial volumetric intravascular ultrasound analysis during half a year after coronary event: The ESTABLISH Study. Circulation 2004; 110: 1061 - 1068.

(11) Sakuma M, Nakamura M, Yamada N, Ota S, Shirato K, Nakano T, et al. Venous thrombolembolism: Deep vein thrombosis with pulmonary embolism, deep vein thrombosis alone, and pulmonary embolism alone. Circ J 2009; 73: $305-309$.

8. (10) Morice MC, Serruys PW, Sousa JE, Fajadet J, Ban Hayashi E, Perin M, et al; RAVEL Study Group. A randomized comparison of a sirolimus-eluting stent with a standard stent for coronary revascularization. $N$ Engl J Med 2002; 346: $1773-1780$.

(10) Connolly SJ, Ezekowitz MD, Yusuf S, Eikelboom J, Oldgren J, Parekh A, et al; RE-LY Steering Committee and Investigators. Dabigatran versus warfarin in patients with atrial fibrillation. N Engl J Med 2009; 361: 1139-1151.

(10) Daemen J, Wenaweser P, Tsuchida K, Abrecht L, Sophia V, Morger C, et al. Early and late coronary stent thrombosis of sirolimus-eluting and paclitaxel-eluting stents in routine clinical practice: Data from a large two-institutional cohort study. Lancet 2007; 369: 667-678.

(10) Iakovou I, Schmidt T, Bonizzoni E, Ge L, Sangiorgi GM, Stankovic G, et al. Incidence, predictors, and outcome of thrombosis after successful implantation of drug-eluting stents. JAMA 2005; 293: 2126-2130.

(10) Joner M, Finn AV, Farb A, Mont EK, Kolodgie FD, Ladich E, et al. Pathology of drug-eluting stents in humans: Delayed healing and late thrombotic risk. J Am Coll Cardiol 2006; 48: 193-202. (Review)

13. (9) Wyse DG, Waldo AL, DiMarco JP, Domanski MJ, Rosenberg Y, Schron EB, et al; Atrial Fibrillation Followup Investigation of Rhythm Management (AFFIRM) Investigators. A comparison of rate control and rhythm control in patients with atrial fibrillation. N Engl J Med 2002; 347: 1825-1833.

(9) Kimura T, Morimoto T, Nakagawa Y, Tamura T, Kadota K, Yasumoto H, et al; j-Cypher Registry Investigators. Antiplatelet therapy and stent thrombosis after sirolimus-eluting stent implantation. Circulation 2009; 119: 987-995.

(9) Nissen SE, Nicholls SJ, Sipahi I, Libby P, Raichlen JS, Ballantyne CM, et al; ASTEROID Investigators. Effect of very high-intensity statin therapy on regression of coronary atherosclerosis: The ASTEROID trial. JAMA 2006; 295: $1556-1565$.

(9) Cheng CI, Lee FY, Chang JP, Hsueh SK, Hsieh YK, Fang CY, et al. Long-term outcomes of intervention for unprotected left main coronary artery stenosis: Coronary stenting vs coronary artery bypass grafting. Circ J 2009; 73: $705-712$.

17. (8) Stone GW, Ellis SG, Cox DA, Hermiller J, O’Shaughnessy C, Mann JT, et al; TAXUS-IV Investigators. A polymer-based, paclitaxel-eluting stent in patients with coronary artery disease. N Engl J Med 2004; 350: 221 - 231.

(8) Katoh H, Shite J, Shinke T, Matsumoto D, Tanino Y, Ogasawara D, et al. Delayed neointimalization on sirolimuseluting stents: 6-month and 12-month follow up by optical coherence tomography. Circ J 2009; 73: 1033-1037. 
(8) JCS Joint Working Group. Guidelines for pharmacotherapy of atrial fibrillation (JCS 2008): Digest version. Circ J 2010; 74: 2479-2500.

(8) Libby P, Okamoto Y, Rocha VZ, Folco E. Inflammation in atherosclerosis: Transition from theory to practice. Circ J 2010; 74: 213-220. (Review)

(8) Chung ES, Leon AR, Tavazzi L, Sun JP, Nihoyannopoulos P, Merlino J, et al. Results of the predictors of response to CRT (PROSPECT) trial. Circulation 2008; 117: 2608-2616.

22. (7) Yamagata K, Kataoka Y, Kokubu N, Kasahara Y, Abe M, Nakajima H, et al. A 3-year clinical outcome after percutaneous coronary intervention using sirolimus-eluting stent and off-pump coronary artery bypass grafting for the treatment of diabetic patients with multivessel disease. Circ J 2010; 74: 671-678.

(7) Tang XL, Rokosh G, Guo YR, Bolli R. Cardiac progenitor cells and bone marrow-derived very small embryonic-like stem cells for cardiac repair after myocardial infarction. Circ J 2010; 74: 390-404. (Review)

(7) Tsuchihashi-Makaya M, Hamaguchi S, Kinugawa S, Yokota T, Goto D, Yokoshiki H, et al; JCARE-CARD Investigators. Characteristics and outcomes of hospitalized patients with heart failure and reduced vs preserved ejection fraction: A report from the Japanese Cardiac Registry of Heart Failure in Cardiology (JCARE-CARD). Circ J 2009; 73: $1893-1900$.

(7) Motoyama S, Sarai M, Harigaya H, Anno H, Inoue K, Hara T, et al. Computed tomographic angiography characteristics of atherosclerotic plaques subsequently resulting in acute coronary syndrome. J Am Coll Cardiol 2009; 54: 49-57.

(7) Falk E, Shah PK, Fuster V. Coronary plaque disruption. Circulation 1995; 92: 657-671. (Review)

(7) Cook S, Wenaweser P, Togni M, Billinger M, Morger C, Seiler C, et al. Incomplete stent apposition and very late stent thrombosis after drug-eluting stent implantation. Circulation 2007; 115: 2426-2434.

(7) Ishigami K, Uemura S, Morikawa Y, Soeda T, Okayama S, Nishida T, et al. Long-term follow-up of neointimal coverage of sirolimus-eluting stents: Evaluation with optical coherence tomography. Circ J 2009; 73: 2300-2307.

(7) Ogawa S, Yamashita T, Yamazaki T, Aizawa Y, Atarashi H, Inoue H, et al; J-RHYTHM Investigators. Optimal treatment strategy for patients with paroxysmal atrial fibrillation: J-RHYTHM Study. Circ J 2009; 73: $242-248$.

(7) Finn AV, Joner M, Nakazawa G, Kolodgie F, Newell J, John MC, et al. Pathological correlates of late drugeluting stent thrombosis: Strut coverage as a marker of endothelialization. Circulation 2007; 115: 2435-2441.

(7) Hirayama A, Saito S, Ueda Y, Takayama T, Honye J, Komatsu S, et al. Qualitative and quantitative changes in coronary plaque associated with atorvastatin therapy. Circ J 2009; 73: 718-725.

32. (6) Van Gelder IC, Hagens VE, Bosker HA, Kingma JH, Kamp O, Kingma T, et al; Rate Control versus Electrical Cardioversion for Persistent Atrial Fibrillation Study Group. A comparison of rate control and rhythm control in patients with recurrent persistent atrial fibrillation. N Engl J Med 2002; 347: 1834-1840.

(6) Leber AW, Becker A, Knez A, von Ziegler F, Sirol M, Nikolaou K, et al. Accuracy of 64-slice computed tomography to classify and quantify plaque volumes in the proximal coronary system: A comparative study using intravascular ultrasound. J Am Coll Cardiol 2006; 47: 672-677. (Review)

(6) Kastrati A, Mehilli J, Pache J, Kaiser C, Valgimigli M, Kelbaek H, et al. Analysis of 14 trials comparing sirolimus-eluting stents with bare-metal stents. N Engl J Med 2007; 356: 1030-1039.

(6) Ishida M, Kato S, Sakuma H. Cardiac MRI in ischemic heart disease. Circ J 2009; 73: 1577-1588. (Review)

(6) Honda Y. Drug-eluting stents: Insights from invasive imaging technologies. Circ J 2009; 73: 1371-1380. (Review)

(6) Nissen SE, Tuzcu EM, Schoenhagen P, Brown BG, Ganz P, Vogel RA, et al; REVERSAL Investigators. Effect of intensive compared with moderate lipid-lowering therapy on progression of coronary atherosclerosis: A randomized controlled trial. JAMA 2004; 291: 1071-1080.

(6) JCS Joint Working Group. Guidelines for diagnosis and treatment of patients with vasospastic angina (coronary spastic angina) (JCS 2008): Digest version. Circ J 2010; 74: 1745-1762.

(6) Motoyama S, Kondo T, Sarai M, Sugiura A, Harigaya H, Sato T, et al. Multislice computed tomographic characteristics of coronary lesions in acute coronary syndromes. J Am Coll Cardiol 2007; 50: 319-326.

(6) Schroeder S, Kopp AF, Baumbach A, Meisner C, Kuettner A, Georg C, et al. Noninvasive detection and evaluation of atherosclerotic coronary plaques with multislice computed tomography. J Am Coll Cardiol 2001; 37: $1430-1435$.

The Editorial Team looks forward to receiving manuscripts with high scientific impact from all over the world.

Hiroaki Shimokawa, MD, $\mathrm{PhD}$

Editor-in-Chief

Circulation Journal

(Released online September 8, 2012) 